\title{
Comparing direct and indirect leaf area measurements for Scots pine and Norway spruce plantations in Sweden
}

\author{
Martin Goude $^{1}$ D . Urban Nilsson ${ }^{1} \cdot$ Emma Holmström $^{1}$
}

Received: 1 April 2019 / Revised: 5 July 2019 / Accepted: 20 August 2019 / Published online: 27 August 2019

(c) The Author(s) 2019

\begin{abstract}
The area of foliage absorbing solar radiation is often expressed as leaf area index (LAI). In this study, specific leaf area (SLA), leaf area at tree level (LA) and LAI at stand level were measured on eight experimental plots of Norway spruce (Picea abies) and Scots pine (Pinus sylvestris), together with tree and stand measurements from biomass harvest. Both projected area and half total surface area were measured, and a model of the relationship between the units was constructed. SLA was larger for pine $\left(61.62 \mathrm{~cm}^{2} \mathrm{~g}^{-1}\right)$ compared to spruce $\left(50.2 \mathrm{~cm}^{2} \mathrm{~g}^{-1}\right)$ and showed a trend of decreasing higher up in the crown. Leaf area was significantly higher for Norway spruce compared to Scots pine on both tree and stand level. Models were constructed using diameter at breast height, tree height and stand basal area to estimate LA. The models were general site-independent models that can be used for easy estimations of single tree leaf area. Indirect measurement of LAI (LAIe) was shown to underestimate LAI with on average 30-73\% depending on species and measurement technique. Using the extensive data collected, conversion models were constructed for estimating LAI from LAIe together with basal area, stem number and stand height. These species-specific conversion models will allow for more accurate estimations of LAI that can be used in mechanistic models of forest growth and for future estimates of LAI from remote sensing data.
\end{abstract}

Keywords Leaf area index $\cdot$ Specific leaf area $\cdot$ Surface area $\cdot$ Hemispherical photography $\cdot$ Plant canopy analyzer . Conversion model

\section{Introduction}

The amount of foliage in a forest has a direct effect on the growth of trees and the growing conditions for understory vegetation (Chen et al. 1997). The amount of leaf material in a forest is often expressed as leaf area index (LAI) (Chen et al. 1997; Gower et al. 1999). The definition of LAI for needle-like leaves has differed among studies over the years, but the most common definition used today is that LAI is half the total green leaf area per unit ground surface area, usually expressed in $\mathrm{m}^{2} \mathrm{~m}^{-2}$ (Chen and Black 1992). Another commonly used definition is projected area of leaves over a unit of land $\left(\mathrm{m}^{2} \mathrm{~m}^{-2}\right)$, but for needle-like leaves these two definitions give different results. For needles with

Communicated by Rüdiger Grote.

Martin Goude

martin.goude@slu.se

1 Southern Swedish Forest Research Centre, SLU, Box 49, 23053 Alnarp, Sweden a three-dimensional shape, the projected area is smaller than half the total surface area, resulting in a smaller LAI (Johnson 1984).

LAI is an important variable because it is a measure of the foliage area available for absorption of solar radiation and is closely related to photosynthetic potential (Bonan 1993). LAI is, therefore, a key component in many physiological and ecological models of plant growth, water use and carbon balance (Chen and Cihlar 1996; Chen et al. 1997; Gower et al. 1999; Gower and Norman 1991). This makes it important when studying water availability and carbon sequestration on both the local and the global scale. One application is in the calculation of light use efficiency (LUE), which is the amount of dry biomass produced per unit of Absorbed Photosynthetic Active Radiation (APAR) (Monteith 1977; Waring et al. 2016).

Stand-level LAI depends on species composition, management interventions and site conditions. Water availability and nitrogen availability are the main site factors influencing LAI in forests and the ability of trees to reach their potential maximum leaf area (Bond-Lamberty et al. 2002; Breda 
et al. 1995; Gonzalez-Benecke et al. 2012; Mccarthy et al. 2007; Ryan et al. 1997; Weiskittel et al. 2008). In evenaged stands, the development of LAI has a similar pattern for most species; it quickly increases to a maximum and then slowly declines later during the rotation (Landsberg and Gower 1997; Ryan et al. 1997). The potential maximum LAI for a species is highly dependent on leaf lifespan and the structure of the canopy (Cannell 1989).

There are different ways to measure LAI, but they can be categorized into two groups: direct and indirect measurements. Direct measurement refers to estimating leaf area from measurements of harvested foliage, either from destructive harvesting of biomass or from collected litterfall (Gower et al. 1999; Jonckheere et al. 2004). Indirect methods estimate LAI with optical instruments. These can be groundbased, like the plant canopy analyzer (LAI-2200C, LI-COR) or hemispherical photography. There are also above-canopy methods like satellite imagery, laser scanning or images from flying drones (Chen 1996; Chen et al. 1997; Jonckheere et al. 2004). Direct methods are the most reliable way of estimating LAI, but indirect methods require less time and labor and are more practical (Barclay 1998; Fassnacht et al. 1994; Gower et al. 1999; Jonckheere et al. 2004; Sampson and Allen 1995).

Even direct methods using sampled biomass require intermediate calculations. The relationship between leaf area and leaf dry biomass, which is known as specific leaf area (SLA, $\mathrm{cm}^{2} \mathrm{~g}^{-1}$ ), has to be calculated in order to upscale leaf measurements to make tree or stand estimations. SLA varies within the crown, where foliage higher up and further out on the branches (sun leaves) has a lower SLA (Konopka et al. 2016; Weiskittel et al. 2008). SLA also varies between trees, being dependent on species, light conditions, age, water availability and nitrogen availability (Hager and Sterba 1985; Landsberg and Gower 1997; Marshall and Monserud 2003; Xiao et al. 2006; Zha et al. 2002).

The indirect measurement approach underestimates LAI compared to direct measurement (Barclay and Trofymow 2000; Gower et al. 1999; Gower and Norman 1991; Mason et al. 2012; Sampson and Allen 1995). Before the underestimated LAI can be used accurately, it must be corrected (Breda 2003). This is often done by using a correction model that is derived from a comparison between direct (reference) and indirect estimates (Chen and Cihlar 1996; Kussner and Mosandl 2000; Stenberg 1996). In radiata pine (Pinus radiata) plantations in New Zealand, Mason et al. (2012) found higher LAI for values when using direct destructive harvesting than with ground-based optical estimations using the LAI 2000 or hemispherical photography. A significant relationship between direct and indirect measurement was found, which was further strengthened when a stand density variable (in this case stems ha ${ }^{-1}$ ) was included. Barclay and Trofymow (2000) also compared the LAI 2000 with direct measurement of LAI for a Douglas-fir (Pseudotsuga menziesii) experiment in Canada. Their indirect measurement values were $26-51 \%$ lower than the direct LAI estimates. They also found a significant relationship between direct and indirect measurement which was further strengthened by including a stem number (stems hal ${ }^{-1}$ ). A reason for the underestimation from indirect measurements based on the Beer-Lambert law is that they assume that the foliage is uniformly and randomly distributed (Demarez et al. 2008; Gower et al. 1999). But forest canopies, especially those of conifers, have very clumped and non-randomly distributed foliage (Chen and Cihlar 1996; Lemeur and Blad 1974; Nilson 1999). This deviation of real forests from ideal models results in optical methods underestimating LAI.

When developing and using climate and carbon balance models, it is crucial to obtain accurate information about leaf area in forests, since they cover such a large part of the world's land area and biomass. In Sweden, productive forest land makes up around 58\% of the total land area (Skogsstyrelsen 2014). The forests are dominated by Scots pine (Pinus sylvestris), which is classified as a light-demanding pioneer species, and Norway spruce (Picea abies), a shade-tolerant secondary species (Eko et al. 2008; Engelmark OH 1999). Together they make up about $80 \%$ of the standing volume on productive forest land (Skogsstyrelsen 2014). The silviculture of these species is well studied, but there is a lack of the data required for accurate leaf area measurement.

In this study, we investigated different leaf area variables (LA, LAI and SLA) for Norway spruce and Scots pine monoculture stands distributed across Sweden. The main goal was to compare directly measured LAI with indirectly measured LAI (LAIe, $\mathrm{m}^{2} \mathrm{~m}^{-2}$ ) with the aim of constructing conversion models that could be used to estimate LAI from LAIe. The relationship of SLA and LA to tree size, stand and site variables was investigated to see whether these measures could be used to construct site-independent models for estimating SLA and LA. When looking at ways of estimating LA, Marklund's biomass equations were also used to calculate needle biomass and from that estimate LA which was compared to measured LA. The studied tree species were also compared for the different leaf area variables to see if the developed models needed to be species specific.

\section{Materials and methods}

\section{Study area}

The LAI measurements were taken at eight experimental sites distributed from the county of Västerbotten in the north of Sweden to the county of Scania in the south (Fig. 1). The measurements were made in established forest experiments for which documented management and stand growth details 


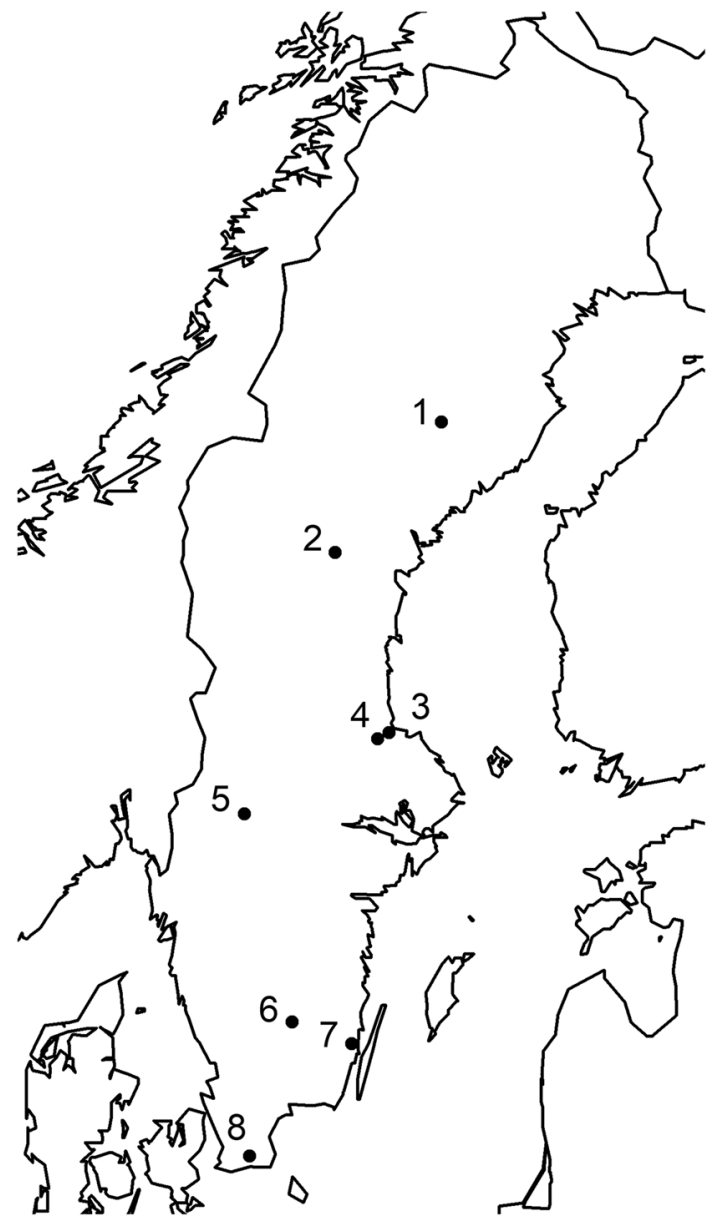

Fig. 1 Location of the experimental sites where LAI was measured. (1) Flakaträsk, (2) Bräcke, (3) Valbo, (4) Främlingshem, (5) Mölnbacka, (6) Asa, (7) Ebbegärde and (8) Snogeholm

were available. All experiments were in even-aged monocultures of Norway spruce and Scots pine. The plot size varied between 373 and $1000 \mathrm{~m}^{2}$ and the age of the plots also varied from 22 to 54 years. The diameter at breast height (DBH) of the sampled trees ranged from 60 to $259 \mathrm{~mm}$ for Norway spruce and 107-307 $\mathrm{mm}$ for Scots pine (Table 1).

\section{Direct leaf area measurement}

Destructive sampling from the biomass harvest and indirect measurement of LAI were conducted outside the growing season, during autumn, winter and early spring (Table 1). All trees in the experimental plots on each site were calipered to determine diameter at breast height, and the diameter distributions of the plots were recorded. Thereafter, a representative sample from the full diameter range was made when selecting the trees taken for biomass. The selected trees were discarded if they had visual signs of defects that might have affected growth, taper or biomass allocation models and each was replaced with another tree of the same diameter.

Branches used for leaf area measurement were collected in the field after felling. The crown was divided into three equal parts: lower (stratum 1), middle (stratum 2) and upper (stratum 3). Four representative living branches were selected from each crown stratum in all directions, 12 branches per tree. Fresh weights of the sampled branches along with the rest of the living crown were taken per strata. Dry weights of the sampled branches were later measured in the laboratory where all samples were separated into branches and needles and dried at $70{ }^{\circ} \mathrm{C}$ for $48 \mathrm{~h}$.

Before the needles were dried, approximately 80 needles were collected from each stratum per tree (20 per sampled branch) for calculation of the total surface area using a method from Johnson (1984). This method uses volume and total length of the needles in the sample in order to calculate surface area. One sample consisted of the 80 needles sampled per stratum and tree. The technique assumes that a cross section of the assembled needles in a fascicle has a circler shape. For Scots pine, the equation from Johnson (1984) was used.

$A=2 l\left(1+\frac{\pi}{n}\right) \sqrt{\frac{V n}{\pi l}}$

where $A$ was the total surface area $\left(\mathrm{cm}^{2}\right), l$ was the cumulative length of the needles in the sample $(\mathrm{cm}), n$ was the number of needles per fascicle, and $V$ was the volume of the needles in the sample $\left(\mathrm{cm}^{3}\right)$.

For Norway spruce, the equation was modified to fit a species with only one needle per fascicle and making the assumption that the needle was made up of segments of cylinders (Homolova et al. 2013). The volume and the total surface area were formulated by Eqs. (2) and (3) (Johnson 1984).

$V=\left(\frac{\pi r^{2}}{n}\right) l$

$A=\left(\frac{2 \pi r}{n}\right) l$

where $r$ was the radius of the section (cm). Equation (2) was solved for $r$.

$r=\sqrt{\frac{V n}{\pi l}}$

Equations (3) and (4) were combined and solved for $A$.

$A=\frac{(l 2 \pi) \sqrt{\frac{V n}{\pi l}}}{n}$

Since the number of needles per fascicle for Norway spruce is one, Eq. 5 can be simplified to: 
Table 1 Experimental sites and measurement details

\begin{tabular}{|c|c|c|c|c|c|c|c|c|}
\hline Site & 1 & 2 & 3 & 4 & 5 & 6 & 7 & 8 \\
\hline Species & $\begin{array}{l}\text { Norway spruce/ } \\
\text { Scots pine }\end{array}$ & $\begin{array}{r}\text { Norway } \\
\text { spruce }\end{array}$ & $\begin{array}{c}\text { Norway } \\
\text { spruce }\end{array}$ & $\begin{array}{l}\text { Norway spruce/ } \\
\text { Scots pine }\end{array}$ & $\begin{array}{l}\text { Norway } \\
\text { Spruce }\end{array}$ & $\begin{array}{l}\text { Norway spruce/ } \\
\text { Scots pine }\end{array}$ & $\begin{array}{l}\text { Norway } \\
\text { Spruce }\end{array}$ & $\begin{array}{l}\text { Norway spruce/ } \\
\text { Scots pine }\end{array}$ \\
\hline $\begin{array}{l}\text { Year of } \\
\text { establish- } \\
\text { ment }\end{array}$ & 1968 & 1983 & 1983 & 1961 & 1983 & 1994 & 1983 & 1992 \\
\hline $\begin{array}{l}\text { Mean plot } \\
\text { size }\left(\mathrm{m}^{2}\right)\end{array}$ & 373 & 1000 & 1000 & 1000 & 1000 & 744 & 625 & 940 \\
\hline $\begin{array}{l}\text { Number } \\
\text { of trees } \\
\text { harvested }\end{array}$ & 16 & 18 & 18 & 18 & 18 & 18 & 18 & 18 \\
\hline $\begin{array}{l}\text { Sample } \\
\text { tree DBH } \\
\text { (mean, } \\
\text { max, min) } \\
(\mathrm{Ns} / \mathrm{Sp}) \\
(\mathrm{mm})\end{array}$ & $\begin{array}{r}(120,180,64.5) / \\
(175,236,112)\end{array}$ & $152,258,63$ & $132,226,60$ & $\begin{array}{l}(148,244,83) / \\
\quad(205,306,106.5)\end{array}$ & $122,169,61$ & $\begin{array}{r}(109,149,64.5) / \\
(153,185,115)\end{array}$ & $126,211,83$ & $\begin{array}{c}(153,174,128) / \\
(142,184,107)\end{array}$ \\
\hline $\begin{array}{l}\text { Destructive } \\
\text { sampling } \\
\text { (season, } \\
\text { year) }\end{array}$ & Autumn, 2015 & $\begin{array}{l}\text { Autumn, } \\
2016\end{array}$ & $\begin{array}{l}\text { Spring, } \\
2017\end{array}$ & Autumn, 2015 & $\begin{array}{l}\text { Spring, } \\
2017\end{array}$ & $\begin{array}{l}\text { Winter, } \\
\text { 2016/2017 }\end{array}$ & $\begin{array}{c}\text { Spring, } \\
2017\end{array}$ & Spring, 2017 \\
\hline $\begin{array}{l}\text { Optical } \\
\text { measure- } \\
\text { ment } \\
\text { (season, } \\
\text { year) }\end{array}$ & Spring, 2016 & $\begin{array}{l}\text { Autumn, } \\
2016\end{array}$ & $\begin{array}{l}\text { Autumn, } \\
2016\end{array}$ & Spring, 2016 & $\begin{array}{l}\text { Autumn, } \\
2016\end{array}$ & Winter, 2016 & $\begin{array}{l}\text { Autumn, } \\
2016\end{array}$ & Spring, 2017 \\
\hline Latitude & 64.2708 & 62.71869 & 60.5769 & 60.5059 & 59.6121 & 57.1407 & 56.8826 & 55.5486 \\
\hline Longitude & 18.4971 & 15.84815 & 17.1886 & 16.9058 & 13.5741 & 14.7673 & 16.2574 & 13.7043 \\
\hline $\begin{array}{l}\text { Altitude (m } \\
\text { a.s.l.) }\end{array}$ & 380 & 400 & 80 & 70 & 100 & 260 & 35 & 55 \\
\hline $\begin{array}{l}\text { Mean } \\
\text { annual } \\
\text { tempera- } \\
\text { ture }\left({ }^{\circ} \mathrm{C}\right)\end{array}$ & 0.6 & 2.2 & 5.2 & 5.2 & 5.9 & 6.1 & 6.5 & 8.2 \\
\hline $\begin{array}{l}\text { Annual pre- } \\
\text { cipitation } \\
(\mathrm{mm})\end{array}$ & 443 & 564 & 618 & 642 & 665 & 617 & 484 & 662 \\
\hline $\begin{array}{c}\text { Growing } \\
\text { season } \\
\text { (days) }\end{array}$ & 150 & 160 & 185 & 185 & 190 & 200 & 200 & 220 \\
\hline $\begin{array}{l}\text { Soil parent } \\
\text { material }\end{array}$ & Sandy-silty till & $\begin{array}{l}\text { Sandy-silty } \\
\text { till }\end{array}$ & $\begin{array}{l}\text { Fine- } \\
\text { grained } \\
\text { tills }\end{array}$ & Sandy-silty till & $\begin{array}{l}\text { Fine- } \\
\text { grained } \\
\text { tills }\end{array}$ & Sandy-silty till & $\begin{array}{l}\text { Sandy-silty } \\
\text { till }\end{array}$ & Fine clay \\
\hline Soil type & Iron podsol & Iron podsol & Iron podsol & Iron podsol & $\begin{array}{l}\text { Brown for- } \\
\text { est soil }\end{array}$ & Iron podsol & Iron podsol & $\begin{array}{l}\text { Brown forest } \\
\text { soil }\end{array}$ \\
\hline $\begin{array}{l}\text { Soil humid- } \\
\text { ity }\end{array}$ & Mesic & Mesic & Mesic & Mesic & Mesic & Mesic & Mesic & Mesic \\
\hline $\begin{array}{l}\text { Ground } \\
\text { vegetation }\end{array}$ & Bilberry & Bilberry & Bilberry & Bilberry & Bilberry & Bilberry & $\begin{array}{l}\text { Soil without } \\
\text { field layer }\end{array}$ & Rich-herb \\
\hline
\end{tabular}

$A=2 \sqrt{V \pi l}$

Volumes were measured using the water displacement principle. The needles were submerged in water, and by measuring the increased volume of the water using a balance, the volume of the needles in the sample was registered. To get the correct volume of the needle sample, volume of the wire holding the needles together was subtracted from the volume increase. Using this method instead of calipering, the needle radius, which has been done in other studies, is easier and may reduce the error in volume estimation (Johnson 1984). 
The needles were digitally scanned, and the lengths of the needles were measured with the ImageJ image analysis software (Schneider et al. 2012). The total surface area was then divided by two to get half the total surface area. In addition, the flat projected area of the needles was measured by highlighting dark pixels in the pictures in ImageJ. Linear regressions of half total surface area and projected area were constructed for each species. Some of the needle samples were measured only for projected area, using ImageJ. These results were converted to half the total surface area using these species-specific regressions.

SLA $\left(\mathrm{cm}^{2} \mathrm{~g}^{-1}\right)$ was calculated for each needle sample (one per crown stratum and tree) by dividing half the total area $\left(\mathrm{cm}^{2}\right)$ of the measured needles by their dry weight $(\mathrm{g})$. A ratio of dry/fresh weight of needles was calculated by dividing sample needle dry weight by the fresh weight of the sampled branches. This ratio was then used to calculate the dry needle weight of the whole stratum. Total needle dry weight $(\mathrm{g})$ together with SLA $\left(\mathrm{cm}^{2} \mathrm{~g}^{-1}\right)$ was then used to calculate half total needle area $\left(\mathrm{cm}^{2}\right)$ for every stratum and summarized to give the half total leaf area for every tree. To get leaf area for all trees in the experimental plots, linear regressions were created for each site with DBH as the explanatory variable. Height was not included in these regressions because there were no measured heights except for the harvested sample trees. Half the total leaf area $\left(\mathrm{m}^{2}\right)$ for each experimental plot was then divided by the plot area $\left(\mathrm{m}^{2}\right)$ to get LAI.

\section{Indirect leaf area measurement}

The indirect (or optical) method of measuring leaf area consisted of measuring diffuse sky radiation with the plant canopy analyzer (LAI-2200C, LI-COR) and with hemispherical photographs taken with a camera with a fisheye lens.

The LAI-2200C calculates LAI by comparing the attenuation of diffuse sky radiation $(<490 \mathrm{~nm})$ above and underneath the forest canopy. Because incoming radiation is blocked by foliage and other vegetation, the radiation levels are lower underneath the canopy compared to above. This difference depends on how much foliage and other objects block the incoming radiation. The terms effective leaf area index (LAIe), effective plant area index (PAIeff) or vegetation plant area index (VAI) have been used in the literature to describe the indirect measurement of LAI that may include non-leafy vegetation (Fassnacht et al. 1994; Garrigues et al. 2008; LI-COR 2013).

The LAI-2200C measurements were taken at 60 points in each plot. These points were systematically allocated on two diagonal transects, 30 along each transect. One wand was used inside the forest for below-canopy readings, and one was set up in an open area nearby, taking above-canopy readings (reference wand). The reference wand was placed on a tripod 2 meters above ground with a $90^{\circ}$ viewing cap, automatically taking a reading every $10 \mathrm{~s}$. The below-canopy wand was handled manually and held $1 \mathrm{~m}$ above ground with a $90^{\circ}$ viewing cap. During all measurements, the wand was held in the same compass direction as the reference wand. The measurements were taken so that as much of the view as possible was within the plots to minimize the effect of the surrounding forest. The readings from the LAI-2200C were imported to the FV2200 software package (version 2.1.1) where the above- and below-canopy readings were paired and an estimate of LAI was obtained using four rings.

The hemispherical photographs were obtained using a Nikon d5300 camera with a Sigma $4.5 \mathrm{~mm}$ F2.8 EX DC circular fisheye lens. The camera was placed on a tripod $1 \mathrm{~m}$ above ground. The pictures were taken at five spots in each plot: one in the middle and four halfway between the center and each corner. The indirect LAI obtained per plot from this was the mean value of these five images. The camera was set up (similarly to the LAI-2200C) to get as much of the view as possible inside the plot and minimize the effect of the area outside the plot. The images were later analyzed using two different software packages, CAN-eye (version 6.47) and Gap Light Analyzer (GLA) (version 2.0). Both software packages analyze gap fraction in the images, and from this, an estimate of LAIe can be obtained.

\section{Data analysis}

All data analyses were conducted using the $\mathrm{R}$ (version 3.3.2) statistical computing platform (Team 2016). The analyses of LA and SLA were based on individual tree data, while analysis of LAI was done at stand level. All leaf area variables were half total surface area. In the analyses, response variables were sometimes log-transformed using the natural logarithm in order to fulfill the assumptions of normality and homoscedasticity. To account for the transformation bias, the correction factor from Baskerville (1972) was used. The same correction needs to be applied when using the models from this study that have log-transformed response variables.

The difference between stratum and between species on tree level was computed using linear mixed models with the lme4 package (Bates et al. 2015), to account for the random effects of site and individual tree. The lmerTest package (Kuznetsova et al. 2017) was used to generate $p$ values in the lmer summary output. $R^{2}$ values were calculated using the MuMIn package (Barton 2018). To test if general individual tree leaf area models could be constructed, linear mixed models were used with DBH and height as fixed tree variables and basal area, stem number, top height, altitude, latitude and stand age as fixed stand variables. The experimental site was kept as a random variable. Compared to the linear models used above to 
calculate direct LAI, these new general models should be independent of site and could include height. The same stand and tree variables that were used for fitting an individual tree leaf area models were also used to test for SLA variation between trees.

To investigate different ways of estimating leaf area at the tree level, biomass functions were used together with mean SLA per species. Species-specific biomass functions from Marklund (1988) were used to calculate tree-level needle dry weight. These biomass equations are based on 1286 trees sampled on 131 sites spread over Sweden, from south to north. The equations are valid for DBH from 0 to $45 \mathrm{~cm}$ for Scots pine and $0-50 \mathrm{~cm}$ for Norway spruce. The transformation correction from Baskerville (1972) was not applied to these functions because they were already adjusted for the log transformation bias. The equation for Norway spruce was:

$$
\begin{aligned}
\log (\text { needles })= & (-1.8551)+9.7809 *\left(\frac{\mathrm{DBH}}{\mathrm{DBH}+12}\right) \\
& -0.4873 * \log (\text { height })
\end{aligned}
$$

The equation for Scots pine was:

$$
\begin{aligned}
\log (\text { needles })= & (-3.4781)+12.1095 *\left(\frac{\mathrm{DBH}}{\mathrm{DBH}+7}\right) \\
& +0.0413 * \text { height }-1.565 * \log (\text { height })
\end{aligned}
$$

where needles were total dry weight $(\mathrm{kg}), \mathrm{DBH}$ was diameter at breast height $(\mathrm{cm})$, and height was height of the tree (m).

The indirect methods of measuring LAI were compared to the direct measurement which was taken as the reference value for LAI at each different site. Linear mixed models were used to estimate LAI from indirectly measured LAIe. The mixed models took into account the random effect of sites. For LAI-2200C, ring five was excluded from the LAIe values. From CAN-eye, the LAI4 value was used as leaf area estimate and from GLA the ring 4 value was used. Since the purpose of the models was to compare direct and indirect LAI, LAIe was always kept in the models. Basal area, stem number, top height, stand age, altitude and latitude were also included in the conversion models, but only retained if they significantly improved the model. The models with significant variables were chosen. VIF values were also evaluated to exclude variables with high autocorrelation. The initial linear model was:

$\mathrm{LAI}=\mathrm{LAIe}+\mathrm{BA}+\mathrm{OH}+\mathrm{Stems}+\mathrm{Alt}+\mathrm{Lat}+\mathrm{Age}$

where LAI was directly measured, LAIe was indirectly estimated leaf area index, BA was basal area $\left(\mathrm{m}^{2} \mathrm{ha}^{-1}\right), \mathrm{OH}$ was top height (m), Stems was number of stems ha ${ }^{-1}$, Alt was altitude (m), Lat was latitude, and Age was stand age (years).

\section{Results}

\section{Projected area versus half total surface area}

The projected area of needle samples was correlated to half the total surface area (Fig. 2). One model was used for both Scots pine and Norway spruce $\left(R^{2}=0.997\right)$ (Table 2). Species-specific models were tested, but there was no difference in slope between pine and spruce. The regression model was created and used for conversion from projected to half total leaf area.

\section{Specific leaf area}

SLA varied between both species and position in the crown. There was a significant difference between SLA for Scots pine and Norway spruce in all strata $(p<0.0001)$, with a higher SLA for pine compared to spruce (Fig. 3). The average SLA per tree was also significantly different with the average SLA for Scots pine being $61.62( \pm 1.36) \mathrm{cm}^{2} \mathrm{~g}^{-1}$ (mean \pm SE) and $50.2( \pm 0.69) \mathrm{cm}^{2} \mathrm{~g}^{-1}$ for Norway spruce. For both species, there were significant differences between all strata $(p<0.0001)$, with lower SLA higher up in the crown (Fig. 3). The effects of individual tree DBH (Fig. 4) and height and stand basal area, stem number, top height, stand age, altitude and latitude were also tested, but no

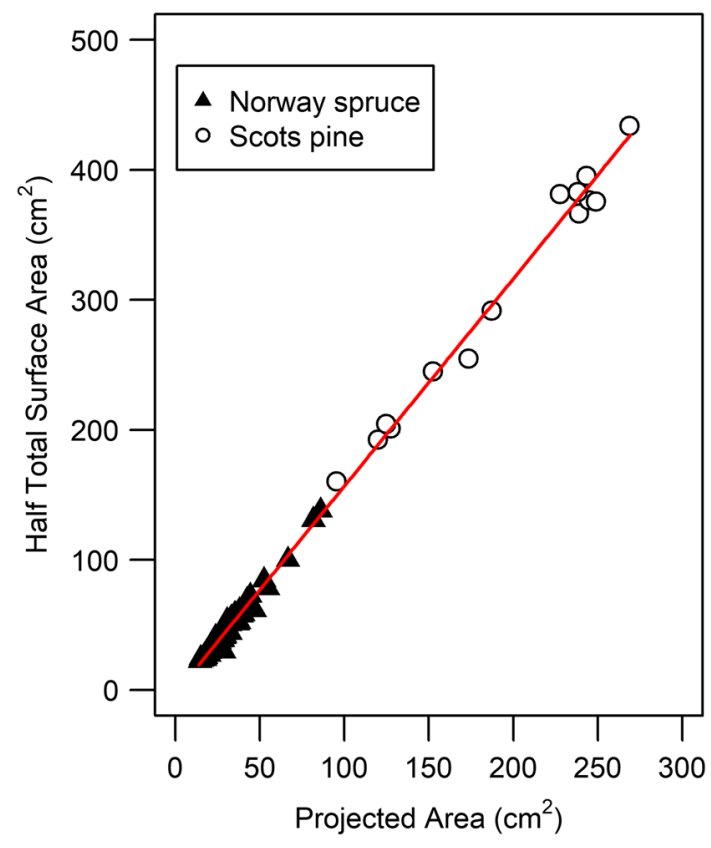

Fig. 2 Projected area $\left(\mathrm{cm}^{2}\right)$ plotted against half total surface area $\left(\mathrm{cm}^{2}\right)$ for needle samples of Scots pine and Norway spruce. The line represents the model presented in Table 2 
Table 2 Regression models for converting projected area $\left(\mathrm{cm}^{2}\right)$ to half total surface area (HTSA, $\mathrm{cm}^{2}$ )

\begin{tabular}{lllllll}
\hline Response variable & Parameter & Estimates & Std. error & $\operatorname{Pr}(>|t|)$ & $R^{2}$ & RMSE \\
\hline HTSA & Intercept & -2.982 & 0.74 & $1.15 \mathrm{e}-4$ & 0.997 & 5.484 \\
& Projected area & 1.597 & 0.009 & $<2 \mathrm{e}-16$ & & \\
\hline
\end{tabular}
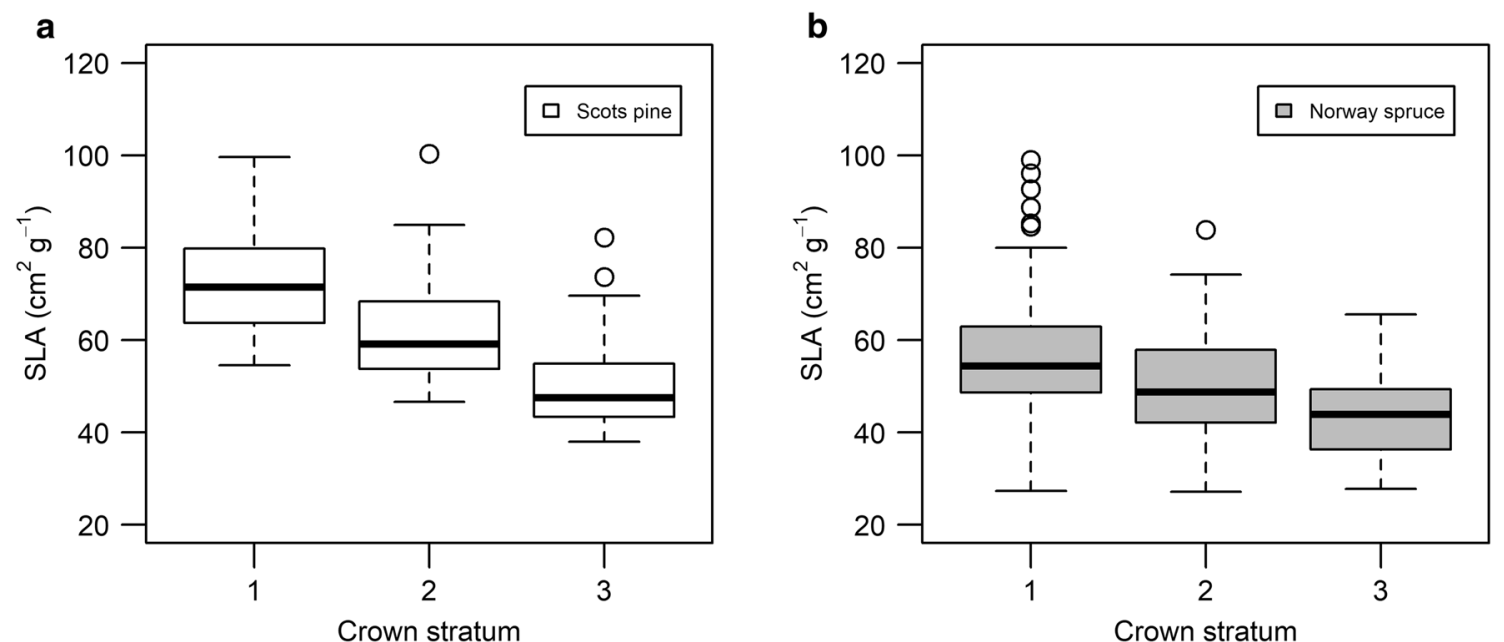

Fig. 3 Specific leaf area (SLA, $\mathrm{cm}^{2} \mathrm{~g}^{-1}$ ) for crown strata 1, 2 and 3 for Scots pine (a) and Norway spruce (b). Each crown stratum was defined as one-third of the living crown with strata 1 in the lowest third, strata 2 in the middle third and strata 3 in the top third

Scots pine, ST 1

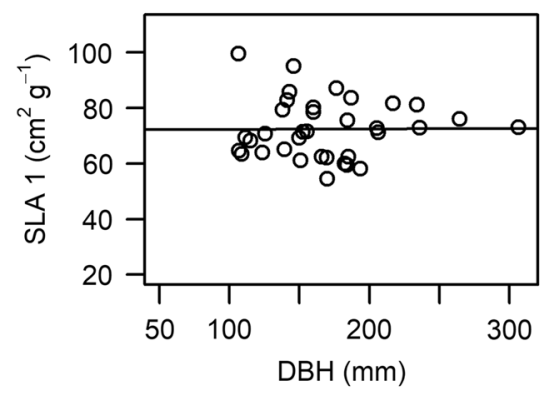

Norway spruce, ST 1

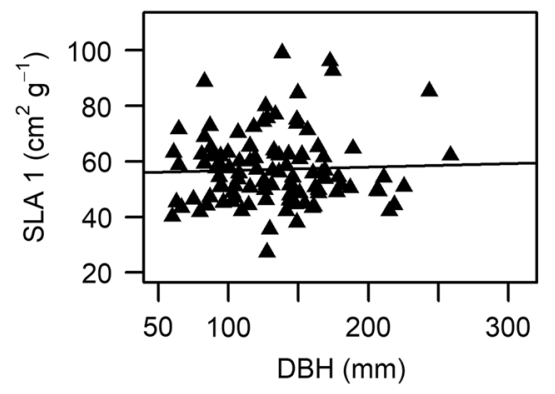

Scots pine, ST 2

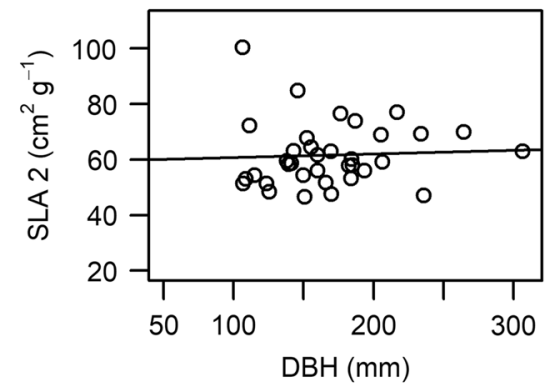

Norway spruce, ST 2

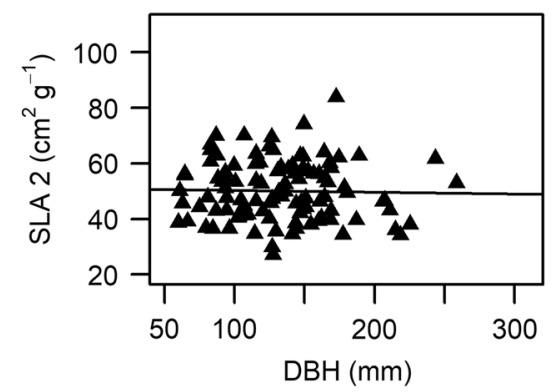

Scots pine, ST 3

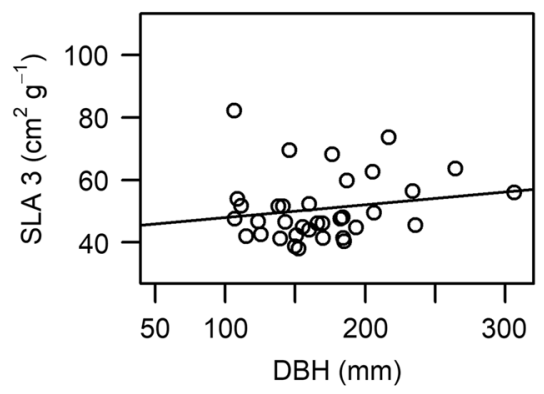

Norway spruce, ST 3

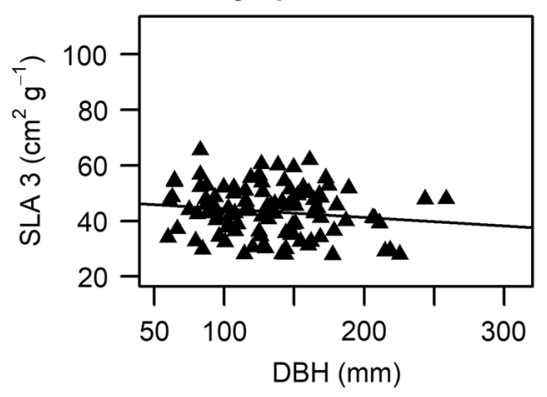

Fig. 4 Specific leaf area (SLA, $\mathrm{cm}^{2} \mathrm{~g}^{-1}$ ) plotted against diameter at breast height (DBH, mm) for three different crown strata (ST 1, 2 and 3, see Fig. 3 for the definition of strata) for Scots pine and Norway spruce. The lines represent linear regressions between SLA and DBH 
significant effect on SLA was detected for either of these variables.

\section{Leaf area}

There was a significant difference in half total leaf area (LA) for individual trees between tree species where
Norway spruce had a higher LA than Scots pine when compared at the same DBH $(p<0.0001)$ (Fig. 5). LA showed a correlation with diameter (Fig. 5), with a larger diameter giving a higher LA for both Scots pine and Norway spruce. The difference in slope was tested for the simple site-specific LA models used to calculate LAI (Fig. 5).

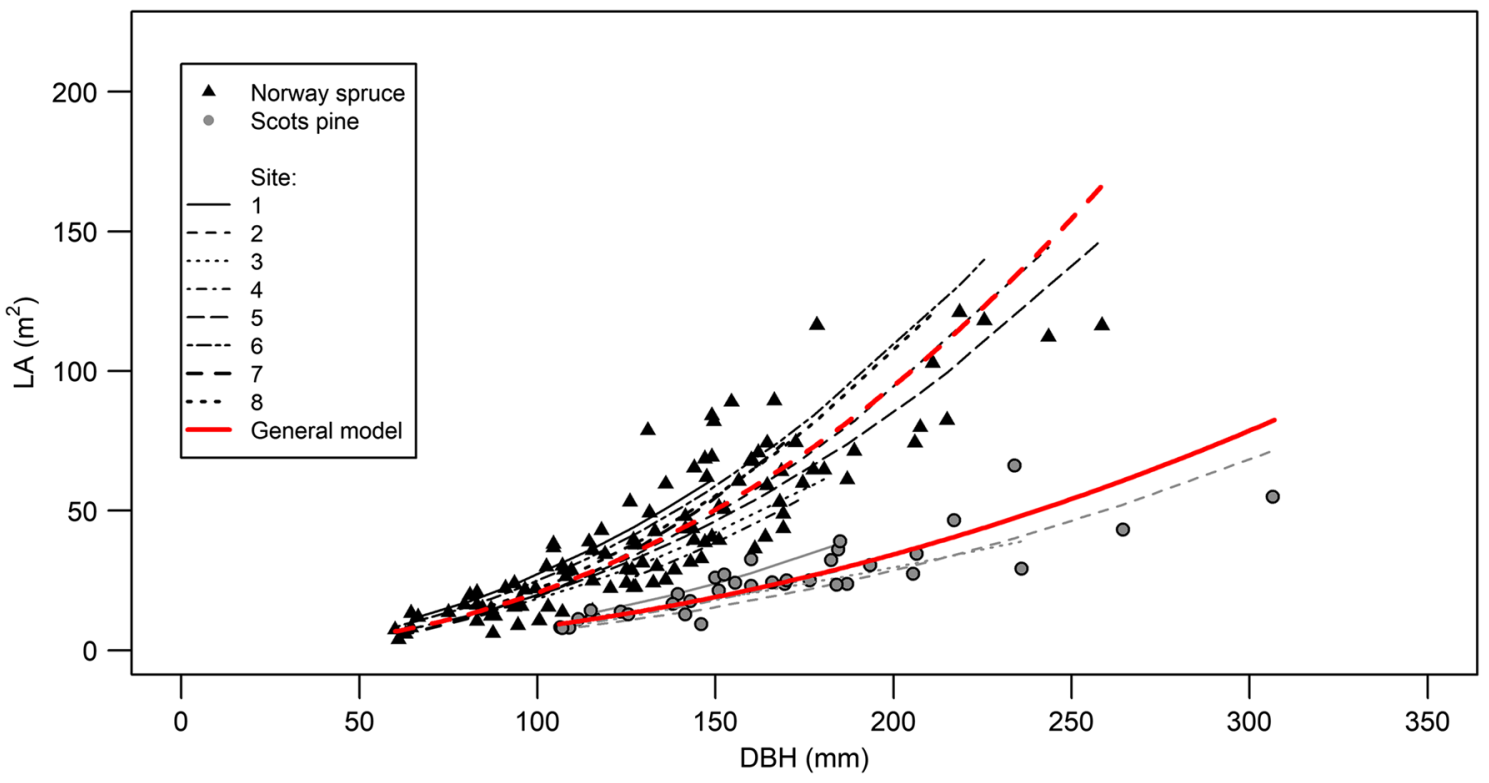

Fig. 5 Half total leaf area (LA, $\mathrm{m}^{2}$ ) for each measured tree plotted against diameter at breast height $(\mathrm{DBH}, \mathrm{mm})$ for Norway spruce and Scots pine. The black and gray lines represent the simple regression

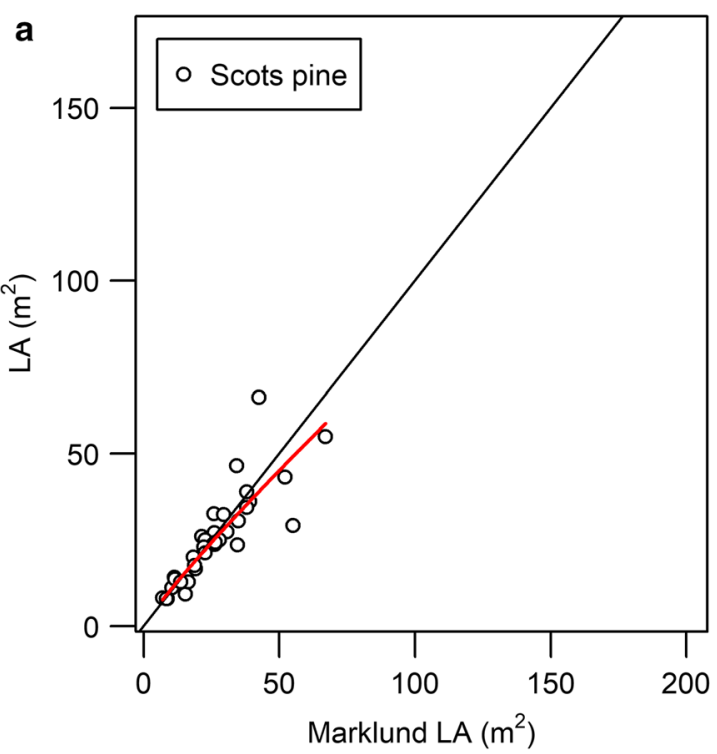

Fig. 6 The measured values of half the total leaf area $\left(\mathrm{LA}, \mathrm{m}^{2}\right)$ for individual trees plotted against LA calculated from Marklund's biomass functions for Scots pine (a) and Norway spruce (b). The black models used to estimate LA for each site. The thick red lines represent the general site-independent models (Table 3) (dashed= Norway spruce and solid $=$ Scots pine)

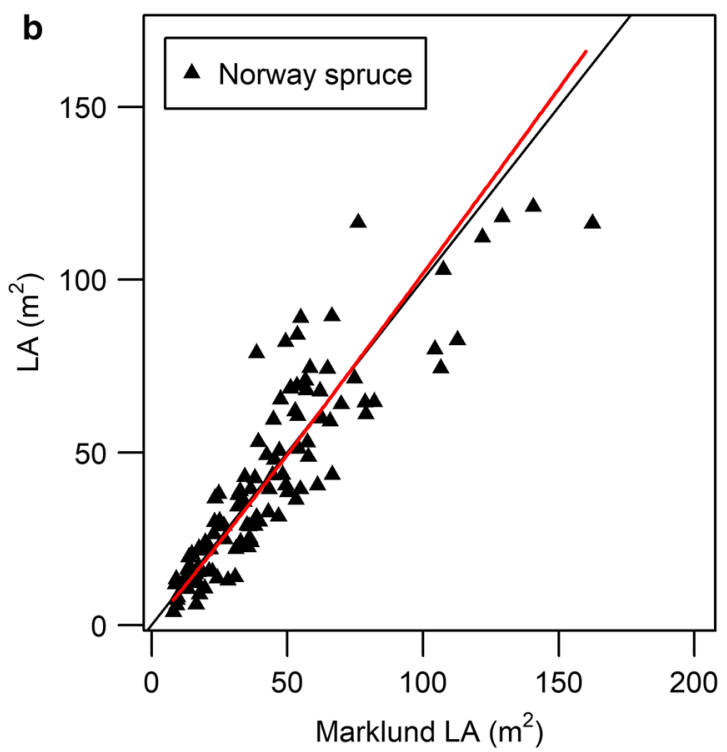

line represents 1 to 1 correlation between directly measured LA and Marklund's LA. The red lines represent the models between measured LA and Marklund's LA (Table 3) 
There was a significant difference in slope between sites for Norway spruce $(p<0.0001)$ but not for Scots pine.

LA calculated from Marklund's biomass functions with mean SLA per species showed a linear correlation with measured LA (Fig. 6). For Norway spruce, Marklund's LA tended to overestimate, especially for higher leaf areas. For Scots pine, Marklund's LA had a higher level of variation at high leaf areas.

Individual tree LA regression models for each species were created (Table 3 ). There were three models per species: one using only tree size, one including tree and stand variables and one using LA estimated with the help from Marklund's biomass equations. DBH alone was significantly correlated with LA for Scots pine $\left(R^{2}=0.8\right)$, whereas, for Norway spruce $\left(R^{2}=0.82\right)$, both tree height and DBH were significant for the model including tree size variables. Including site variables, DBH together with basal area was significantly correlated with LA for Scots pine $\left(R^{2}=0.86\right)$. Including site variables with Norway spruce gave a model including DBH, height and basal area $\left(R^{2}=0.85\right)$. Models using leaf area estimated from Marklund's biomass functions showed high correlations with LA for both pine $\left(R^{2}=0.84\right)$ and spruce $\left(R^{2}=0.82\right)$ (Table 3$)$. For Norway spruce, the model using Marklund's biomass had a slope that was not significantly different from 1 .

\section{Leaf area index}

Directly measured LAI was significantly higher for Norway spruce than for Scots pine when compared at the same basal area ( $p$ value $<0.0001$; Fig. 7 ). LAI for spruce and pine was both positively correlated with basal area (Fig. 7).

For both Scots pine and Norway spruce, LAIe measured indirectly by LAI-2200C, CAN-eye and GLA was correlated with directly measured LAI but showed a general underestimation (Fig. 8). The relationships between LAI and LAIe from CAN-eye and GLA for Norway spruce were nonlinear. For Scots pine, the underestimation was on average 30\% $( \pm 1.14)$ for LAI-2200C, $73 \%( \pm 0.82)$ for CAN-eye and $62 \%$ $( \pm 0.81)$ for GLA compared to the direct measurement. For Norway spruce, the underestimation was $32 \%( \pm 2.1)$ on average for LAI-2200C, $72 \%( \pm 1.05)$ for CAN-eye and $67 \%$ $( \pm 1.07)$ for GLA. The underestimation from LAI-2200C, CAN-eye and GLA was higher at higher LAI for Norway spruce but not for Scots pine.

Different models for converting LAIe were constructed, and they are presented in Table 4 . The models for LAI-2200C estimates consisted of LAIe and stem number $\left(\right.$ stems ha $\left.{ }^{-1}\right)$ for Scots pine $\left(R^{2}=0.87\right)$ and LAIe together with basal area $\left(\mathrm{m}^{2} \mathrm{ha}^{-1}\right)$ for Norway spruce $\left(R^{2}=0.90\right)$. The models for GLA estimates consisted of

Table 3 Models of half total leaf area $\left(\mathrm{LA}, \mathrm{m}^{2}\right)$ for individual trees as a function of tree size variables; diameter breast height (DBH, $\left.\mathrm{mm}\right)$ and tree height (height, $\mathrm{m}$ ) and stand variables; basal area $\left(\mathrm{m}^{2} \mathrm{ha}^{-1}\right)$. Site was set as random effect

\begin{tabular}{|c|c|c|c|c|c|c|c|c|}
\hline Species & Response variable & Parameter & Estimates & Std.error & $\operatorname{Pr}(>|t|)$ & $R^{2}$ & RMSE & Random variance \\
\hline \multirow[t]{3}{*}{ Scots pine } & $\log (\mathrm{LA})$ & Intercept & -7.316 & 0.44 & $<2 \mathrm{e}-16$ & 0.8 & 0.192 & \\
\hline & & $\log (\mathrm{DBH})$ & 2.045 & 0.09 & $<2 \mathrm{e}-16$ & & & \\
\hline & & Site (random) & & & & & & 0.324 \\
\hline \multirow[t]{4}{*}{ Scots pine } & $\log (\mathrm{LA})$ & Intercept & -6.721 & 0.459 & $<2 \mathrm{e}-16$ & 0.86 & 0.19 & \\
\hline & & $\log (\mathrm{DBH})$ & 2.012 & 0.083 & $<2 \mathrm{e}-16$ & & & \\
\hline & & Basal area & -0.013 & 0.004 & 0.012 & & & \\
\hline & & Site (random) & & & & & & $9.804 e-3$ \\
\hline \multirow[t]{4}{*}{ Norway spruce } & $\log (\mathrm{LA})$ & Intercept & -8.31 & 0.33 & $<2 \mathrm{e}-16$ & 0.82 & 0.276 & \\
\hline & & $\log (\mathrm{DBH})$ & 2.61 & 0.09 & $<2 \mathrm{e}-16$ & & & \\
\hline & & Height & -0.07 & 0.01 & $3.63 \mathrm{e}-08$ & & & \\
\hline & & Site (random) & & & & & & 0.028 \\
\hline \multirow[t]{5}{*}{ Norway spruce } & $\log (\mathrm{LA})$ & Intercept & -7.579 & 0.317 & $<2 \mathrm{e}-16$ & 0.85 & 0.252 & \\
\hline & & $\log (\mathrm{DBH})$ & 2.435 & 0.085 & $<2 \mathrm{e}-16$ & & & \\
\hline & & Height & -0.021 & 0.012 & $6.13 e-3$ & & & \\
\hline & & Basal area & -0.019 & 0.002 & $<2 \mathrm{e}-16$ & & & \\
\hline & & Site (random) & & & & & & 0.036 \\
\hline \multirow[t]{3}{*}{ Scots pine } & $\log (\mathrm{LA})$ & Intercept & 0.286 & 0.13 & 0.0259 & 0.84 & 0.194 & \\
\hline & & $\log ($ Marklund LA) & 0.896 & 0.04 & $<2 \mathrm{e}-16$ & & & \\
\hline & & Site (random) & & & & & & $6.733 e-3$ \\
\hline \multirow[t]{3}{*}{ Norway spruce } & $\log (\mathrm{LA})$ & Intercept & -0.21 & 0.11 & 0.0547 & 0.82 & 0.276 & \\
\hline & & $\log ($ Marklund LA) & 1.041 & 0.024 & $<2 \mathrm{e}-16$ & & & \\
\hline & & Site (random) & & & & & & 0.03 \\
\hline
\end{tabular}




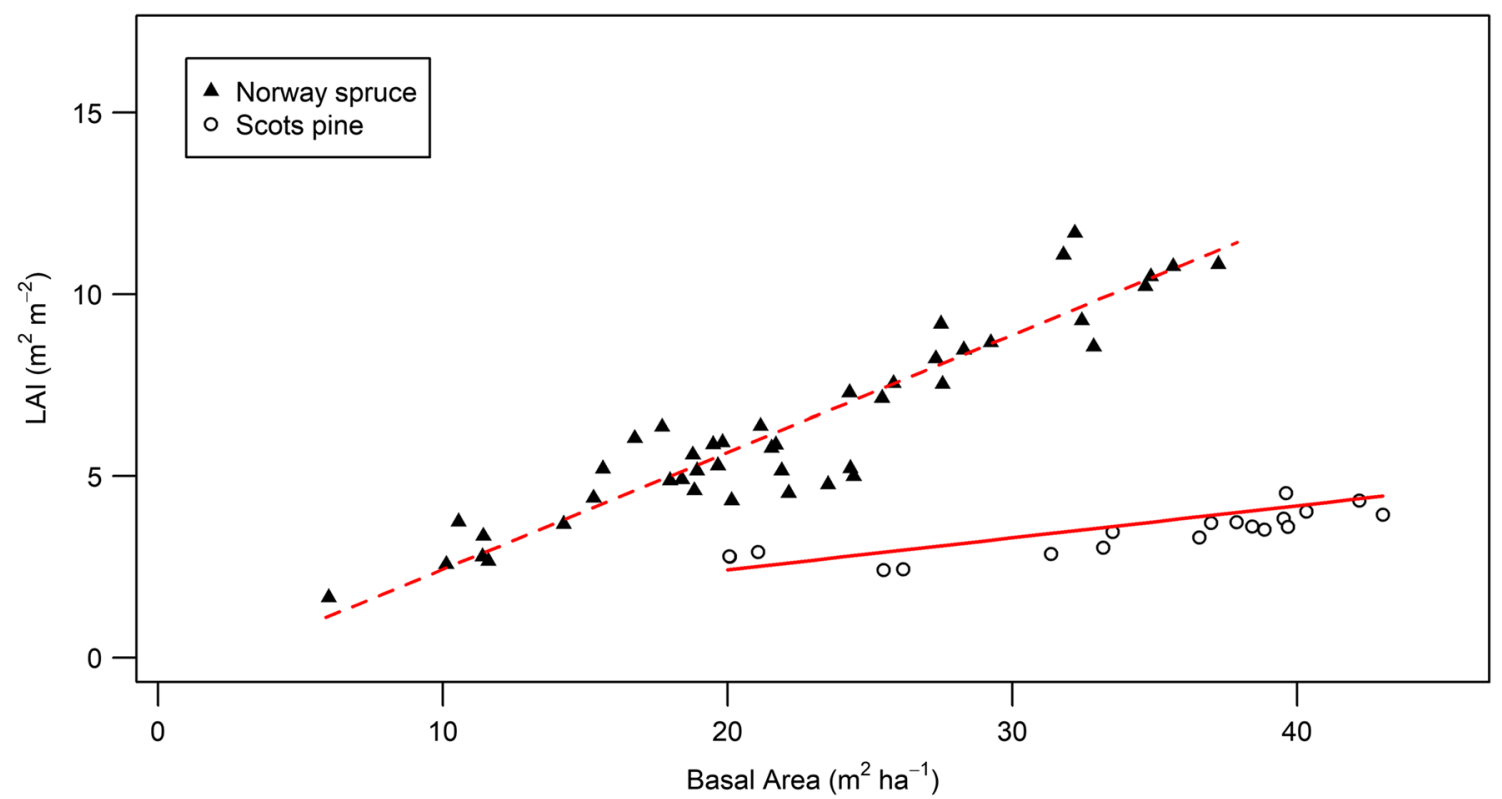

Fig. 7 Direct measured LAI $\left(\mathrm{m}^{2} \mathrm{~m}^{-2}\right)$ for Norway spruce and Scots pine plotted against basal area $\left(\mathrm{m}^{2} \mathrm{ha}^{-1}\right)$. The lines represent the models between LAI and basal area (Table 4$)($ dashed $=$ Norway spruce and solid $=$ Scots pine)

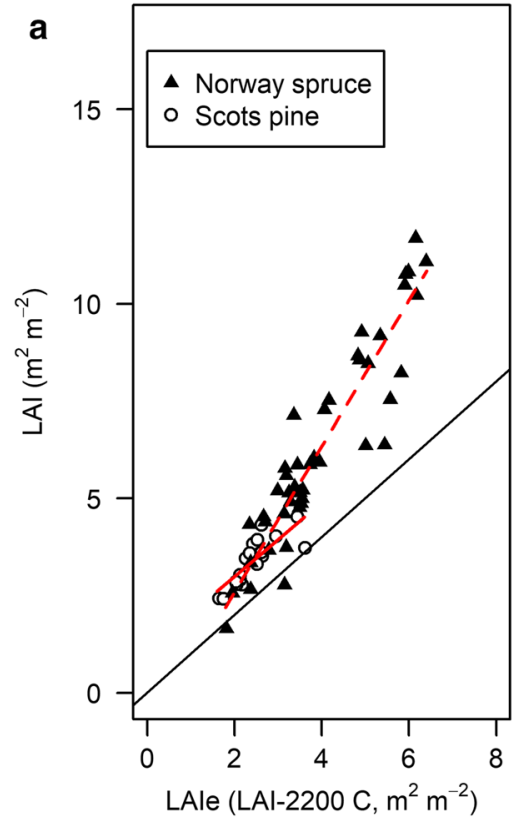

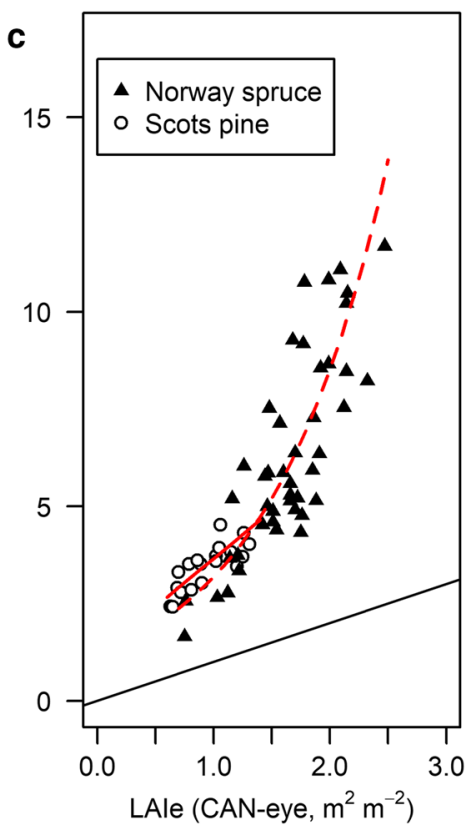

Fig. 8 Directly measured LAI $\left(\mathrm{m}^{2} \mathrm{~m}^{-2}\right)$ for Norway spruce and Scots pine plotted against LAIe $\left(\mathrm{m}^{2} \mathrm{~m}^{-2}\right)$ obtained from LI-COR LAI-2200c (a), Gap Light Analyzer (GLA) (b) and CAN-eye (c).

LAIe and top height $(\mathrm{m})$ for pine $\left(R^{2}=0.77\right)$ and LAIe together with basal area $\left(\mathrm{m}^{2} \mathrm{ha}^{-1}\right)$ for spruce $\left(R^{2}=0.94\right)$. The models for CAN-eye estimates were made up by LAIe for pine $\left(R^{2}=0.59\right)$ and LAIe with basal area $\left(\mathrm{m}^{2} \mathrm{ha}^{-1}\right)$ for spruce $\left(R^{2}=0.86\right)$. Two models were also constructed
The black line represents a 1 to 1 correlation between LAI and LAIe. The red lines represent the models between LAI and LAIe (Table 4) $($ dashed $=$ Norway spruce and solid $=$ Scots pine $)$

using only stand variables. For both Scots pine $\left(R^{2}=0.68\right)$ and Norway spruce $\left(R^{2}=0.86\right)$, basal area made up this model. 
Table 4 Models of directly measured LAI $\left(\mathrm{m}^{2} \mathrm{~m}^{-2}\right)$ as a function of indirectly measured LAIe $\left(\mathrm{m}^{2} \mathrm{~m}^{-2}\right)$ and stand variables such as number of stems (Stems, stems ha $\left.{ }^{-1}\right)$, top height $(\mathrm{OH}, \mathrm{m})$ and basal area $\left(\mathrm{m}^{2} \mathrm{ha}^{-1}\right)$. Site was set as random effect

\begin{tabular}{|c|c|c|c|c|c|c|c|c|c|}
\hline Device & Species & Response variable & Parameter & Estimates & Std. error & $\operatorname{Pr}(>|t|)$ & $R^{2}$ & RMSE & Random variance \\
\hline LAI-2200 C & Scots pine & LAI & $\begin{array}{l}\text { Intercept } \\
\text { LAIe } \\
\text { Stems } \\
\text { Site (random) }\end{array}$ & $\begin{array}{l}0.766 \\
0.427 \\
1.117 \mathrm{e}-04\end{array}$ & $\begin{array}{l}0.3485 \\
0.144 \\
2.184 \mathrm{e}-04\end{array}$ & $\begin{array}{l}0.048 \\
8.92 \mathrm{e}-3 \\
8.66 \mathrm{e}-5\end{array}$ & 0.8 & 0.212 & 0.036 \\
\hline LAI-2200 C & Norway spruce & LAI & $\begin{array}{l}\text { Intercept } \\
\text { LAIe } \\
\text { Basal area } \\
\text { Site (random) }\end{array}$ & $\begin{array}{l}-1.065 \\
0.438 \\
0.255\end{array}$ & $\begin{array}{l}0.347 \\
0.15 \\
0.025\end{array}$ & $\begin{array}{l}6.49 \mathrm{e}-3 \\
5.84 \mathrm{e}-3 \\
6.33 \mathrm{e}-13\end{array}$ & 0.90 & 0.419 & 0.46 \\
\hline CAN-eye & Scots pine & LAI & $\begin{array}{l}\text { Intercept } \\
\text { LAIe } \\
\text { Site (random) }\end{array}$ & $\begin{array}{l}1.184 \\
2.472\end{array}$ & $\begin{array}{l}0.54 \\
0.535\end{array}$ & $\begin{array}{l}5.38 \mathrm{e}-2 \\
4.46 \mathrm{e}-4\end{array}$ & 0.59 & 0.312 & 0.111 \\
\hline CAN-eye & Norway spruce & $\log (\mathrm{LAI})$ & $\begin{array}{l}\text { Intercept } \\
\text { LAIe } \\
\text { Basal area } \\
\text { Site (random) }\end{array}$ & $\begin{array}{l}0.276 \\
0.334 \\
0.042\end{array}$ & $\begin{array}{l}0.086 \\
0.067 \\
3.411 \mathrm{e}-03\end{array}$ & $\begin{array}{l}3.45 \mathrm{e}-3 \\
1.62 \mathrm{e}-5 \\
1.38 \mathrm{e}-14\end{array}$ & 0.86 & 0.09 & 0.022 \\
\hline GLA & Scots pine & LAI & $\begin{array}{l}\text { Intercept } \\
\text { LAIe } \\
\text { OH } \\
\text { Site (random) }\end{array}$ & $\begin{array}{l}-1.092 \\
2.774 \\
0.048\end{array}$ & $\begin{array}{l}0.751 \\
0.352 \\
0.023\end{array}$ & $\begin{array}{l}0.164 \\
4.38 \mathrm{e}-07 \\
4.82 \mathrm{e}-2\end{array}$ & 0.77 & 0.285 & 0.025 \\
\hline GLA & Norway spruce & $\log (\mathrm{LAI})$ & $\begin{array}{l}\text { Intercept } \\
\text { LAIe } \\
\text { Basal area } \\
\text { Site (random) }\end{array}$ & $\begin{array}{l}0.109 \\
0.505 \\
0.032\end{array}$ & $\begin{array}{l}0.075 \\
0.066 \\
3.509 \mathrm{e}-03\end{array}$ & $\begin{array}{l}0.152 \\
2.75 e-9 \\
2.77 e-11\end{array}$ & 0.94 & 0.079 & $6.307 e-3$ \\
\hline Stand variable & Scots pine & LAI & $\begin{array}{l}\text { Intercept } \\
\text { Basal area } \\
\text { Site (random) }\end{array}$ & $\begin{array}{l}0.651 \\
0.088\end{array}$ & $\begin{array}{l}0.251 \\
3.28 \mathrm{e}-03\end{array}$ & $\begin{array}{l}0.054 \\
2.28 \mathrm{e}-14\end{array}$ & 0.68 & 0.057 & 0.202 \\
\hline Stand variable & Norway spruce & LAI & $\begin{array}{l}\text { Intercept } \\
\text { Basal area } \\
\text { Site (random) }\end{array}$ & $\begin{array}{l}-0.799 \\
0.322\end{array}$ & $\begin{array}{l}0.4 \\
0.01\end{array}$ & $\begin{array}{l}4.33 e-2 \\
<2 e-16\end{array}$ & 0.86 & 0.434 & 0.813 \\
\hline
\end{tabular}

\section{Discussion}

Estimating LAI in a reliable way is important for the use and construction of climate-sensitive and physiological growth models. The results of this study show that LA can be estimated from diameter and height and that LAI can be estimated with the help of optical instruments and stand density measures. The comparison of the two species also shows the importance of developing species-specific models.

Comparing direct and indirect measurements of LAI showed that it was generally underestimated by LAIe, with the amount of underestimation depending on species and measurement technique. The greater underestimation for Norway spruce compared to Scots pine could be a result of differences in canopy structure and foliage clumping between the two species, since these factors are the main reasons for underestimation of LAI (Gower and Norman 1991). Norway spruce needles are smaller than Scots pine needles (about 1/5 of the area), and at stand level, the foliage in a spruce forest is clustered around slim branches and narrow canopies with a high degree of overlap and self-shading. In comparison, Scots pine has higher raised crowns with longer needles and less self-shading.

Underestimation was also correlated with higher LAI, and since spruce had a higher LAI this could explain the higher level of underestimation. Indirect measurements of leaf area based on optical estimation of canopy cover have been shown to be less accurate in forests with more foliage overlap (Sampson and Allen 1995). In this study, it was spruce forests that had high LAI and extensive overlap. Since the hemispherical photography method uses only a two-dimensional picture, it is also more affected by canopy overlapping, and this could be a reason why there was greater underestimation for GLA and CAN-eye compared to the LI-COR. 
A relationship between LAI and LAIe was shown for both Scots pine and Norway spruce with all indirect methods. This finding, together with the observed underestimation, shows the usefulness of conversion models. For LI-COR estimations, the explanatory variable apart from LAIe was basal area for spruce and stem number for pine. Previous studies have also shown that LAI is related to stand density, and LAIe together with a measure of stand density can be used to estimate LAI (Barclay and Trofymow 2000; Gonzalez-Benecke et al. 2012; Mason et al. 2012). If both basal area and LAIe were included for pine, for all indirect methods, the latter independent variable was not significant. This was due to the high level of correlation between the two variables.

Looking at this study, it is difficult to rank the different indirect methods. They all have different advantages and disadvantages that a user has to consider and decide what is important for the specific case. The LI-COR had less underestimation and showed a good result in the correction models for both species. It was also a less subjective measurement method compared to the more or less subjective analyses of hemispherical photographs where the user manually processes the images. Looking at the whole process though, the hemispherical method, just using a camera with a fisheye lens, is easier to access and faster to use in the field compared to the LI-COR. If the goal is to get more people to measure LAI, the hemispherical photography method is a good way to go.

For leaf area at the tree level, there was a correlation with diameter at breast height (DBH) and tree height for Norway spruce. Including site variables such as basal area improved the models (Table 3), since basal area added a measure of competition between trees to the model. With higher density and basal area, the competition for light becomes higher, and leaf area on tree level was negatively affected. The correlation with DBH is consistent with previous literature studies which have resulted in the method of direct measurement of leaf area with the help of allometric relationships, where the relationship between LA for individual trees and tree size variables (often diameter) is used to estimate LA for all trees in a plot whose diameter has been measured (Gower et al. 1999). Our study utilized these relationships by using simple site- and species-specific relations between DBH and individual tree LA to calculate LA for all trees in a plot. As seen in Fig. 5, there was some tendency of differences between sites and for Norway spruce, the slopes of the site LA models were significantly different between sites. This indicates that site-specific models should be preferred when they can be developed, but our general LA models (Table 3) also show that individual tree LA can be reliably estimated independent of site.

Estimates of leaf area at the individual tree level, using Marklund's biomass functions to first estimate needle biomass and then use mean SLA to estimate LA, were relatively accurate compared to the more labor-intensive direct measurement. Both this and the models that estimated LA from diameter and height show the potential of using tree size measurements to estimate LA (Mason et al. 2012; Xiao et al. 2006). Together with the ability to estimate LAI from stand variables, this gives an opportunity not just to estimate leaf area without the use of optical techniques and biomass harvests but also to estimate it from data sets in which leaf area was never measured.

The measured and estimated LA and LAI showed a clear species difference between Norway spruce and Scots pine. This difference could be explained by foliage longevity and canopy structure which have a major influence on potential maximum LAI and LA (Cannell 1989). Since the two species were growing under the same conditions in our study, it is likely that foliage longevity has a large influence on leaf area. Norway spruce is a shade-tolerant species and can withstand self-shading to a large extent. Needle longevity in this species is normally $7-15$ years, and it can, therefore, build up a large canopy. Scots pine, on the other hand, is a more shade-intolerant species which cannot withstand self-shading to such a degree, and it has a needle longevity of 2-6 years and therefore cannot develop a large canopy (Albrektson et al. 2012).

SLA differed depending on the crown position for both Scots pine and Norway spruce, with lower SLA values higher up in the crown. This agrees with previous studies with similar results (Hager and Sterba 1985; Marshall and Monserud 2003; Weiskittel and Maguire 2007). SLA was also tested against DBH and height of the measured trees, but no significant correlation was found for either of the species. This agrees with previous results (Weiskittel et al. 2008), where no correlation between SLA and tree size was found. However, other studies have shown such a correlation. For Norway spruce, SLA was found to be correlated with diameter and height (Hager and Sterba 1985; Niinemets and Kull 1995) and a correlation between tree size and SLA for Douglas-fir has also been suggested (Stclair 1994). The difficulties of finding relationships with tree size and SLA are likely because SLA is dependent on light conditions for the tree, which is not affected by age and size for a tree in a closed canopy homogenous forest.

None of the leaf area variables were correlated to age. Age has been shown to be correlated to leaf area development and light availability (Landsberg and Gower 1997) which is connected to SLA (Konopka et al. 2016; Temesgen and Weiskittel 2006). Leaf area increase in pure stands has an initial rapid development and becomes relatively stable over age for a specific stand, (Landsberg and Gower 1997; Ryan et al. 1997). However, the development rate may vary with site productivity and management. The big range in latitude and altitude of the data could be suspected to have a 
significant effect on leaf area since other studies have found a correlation between latitude and foliage properties traits (Landsberg and Gower 1997; Pensa et al. 2007). This was why latitude and altitude were tested, but no significant correlation with any of the leaf area variables could be found. The reason for this could be the big variation within sites with the same latitude and altitude.

The strong correlation between projected and half total surface area allowed for conversion from projected area for those plots that were not measured for total surface area. Other studies have shown a similarly strong correlation between projected and total surface area for both Scots pine and Norway spruce (Homolova et al. 2013; Johnson 1984; Lang 1991; Riederer et al. 1988). Knowing this relationship is important because it allows for easier comparison between studies using different definitions of leaf area.

The limitations of this study were the range and size of the data set. For practical and economic reasons, biomass harvest was conducted in young to middle-aged experimental plots. This makes it difficult to accurately estimate leaf area for large trees and old forests. The size of the data set and the lack of similar leaf area data did not allow for testing of the models and validation against independent data. This made it difficult to evaluate and rank the models and methods. Further studies are needed to improve the conversions from LAIe to LAI and achieve better estimation from stand and tree measurements by including older forests and bigger trees. If the use of LAI in forestry is to increase, other species and mixed forests also need to be studied. The models created are robust general tree and stand-level models. This means that some of the information about leaf area variation within crown was lost. To answer questions about leaf area variation on tree and stand level, new studies need to focus on this. Future studies also need to investigate withingrowing season LAI development and how LAI is affected by forest management practices.

\section{Conclusion}

LAI of Norway spruce and Scots pine monoculture stands can be reliably estimated with LAIe combined with a conversion model including stand variables such as top height, stem number and basal area. LA for individual spruce and pine trees can be estimated from diameter and height using both LA models developed in this study and with existing biomass equations using mean species-specific SLA. The species differences in leaf area show that models used to estimate leaf area should be species specific. The results from this study make it easier to accurately estimate leaf area which will hopefully be more widely used for these species in for example the development of new forest growth and climate models. The ability to estimate LAI and LA from tree and stand measures also gives the opportunity to estimate leaf area for data sets where it was never measured.

Acknowledgements Open access funding provided by Swedish University of Agricultural Sciences. We gratefully acknowledge field assistance from the Unit for Field-based Forest Research, SLU. Funding for this work was provided in part by "Karl Erik Önnesjös stiftelse för vetenskaplig forskning och utveckling" and by the research program Trees and Crops for the Future, TC4F.

Author contribution MG was the main researcher and responsible for data collection, data analysis and manuscript writing. UN and $\mathrm{EH}$ contributed with valuable support during data analysis and manuscript writing, and helped to improve the overall paper.

\section{Compliance with ethical standards}

Conflict of interest The authors declare that they have no conflict of interest.

Open Access This article is distributed under the terms of the Creative Commons Attribution 4.0 International License (http://creativeco mmons.org/licenses/by/4.0/), which permits unrestricted use, distribution, and reproduction in any medium, provided you give appropriate credit to the original author(s) and the source, provide a link to the Creative Commons license, and indicate if changes were made.

\section{References}

Albrektson A, Elfving B, Lundqvist L, Valinger E (2012) Skogsskötselserien - Skogsskötselns grunder och samband. Skogsstyrelsen

Barclay HJ (1998) Conversion of total leaf area to projected leaf area in lodgepole pine and Douglas-fir. Tree Physiol 18:185-193

Barclay HJ, Trofymow JA (2000) Relationship of readings from the LICOR canopy analyzer to total one-sided leaf area index and stand structure in immature Douglas-fir. For Ecol Manag 132:121-126. https://doi.org/10.1016/S0378-1127(99)00222-4

Barton K (2018) MuMIn: multi-model inference. https://CRAN.Rproject.org/package $=$ MuMIn. Accessed 25 May 2018

Baskerville GL (1972) Use of logarithmic regression in the estimation of plant biomass. Can J For Res 2:49-53

Bates D, Machler M, Bolker BM, Walker SC (2015) Fitting linear mixed-effects models using lme4. J Stat Softw 67:1-48

Bonan GB (1993) Importance of leaf-area index and forest type when estimating photosynthesis in boreal forests. Remote Sens Environ 43:303-314. https://doi.org/10.1016/0034-4257(93)90072-6

Bond-Lamberty B, Wang C, Gower ST, Norman J (2002) Leaf area dynamics of a boreal black spruce fire chronosequence. Tree Physiol 22:993-1001

Breda NJJ (2003) Ground-based measurements of leaf area index: a review of methods, instruments and current controversies. J Exp Bot 54:2403-2417. https://doi.org/10.1093/jxb/erg263

Breda N, Granier A, Aussenac G (1995) Effects of thinning on soil and tree water relations, transpiration and growth in an oak forest (Quercus petraea (Matt) Liebl). Tree Physiol 15:295-306

Cannell MGR (1989) Physiological basis of wood production: a review scand. J For Res 4:459-490. https://doi.org/10.1080/0282758890 9382582

Chen JM (1996) Optically-based methods for measuring seasonal variation of leaf area index in boreal conifer stands. Agric For Meteorol 80:135-163. https://doi.org/10.1016/0168-1923(95)02291-0 
Chen JM, Black TA (1992) Defining leaf-area index for nonflat leaves. Plant Cell Environ 15:421-429. https://doi. org/10.1111/j.1365-3040.1992.tb00992.x

Chen JM, Cihlar J (1996) Retrieving leaf area index of boreal conifer forests using landsat TM images. Remote Sens Environ 55:153162. https://doi.org/10.1016/0034-4257(95)00195-6

Chen JM, Rich PM, Gower ST, Norman JM, Plummer S (1997) Leaf area index of boreal forests: theory, techniques, and measurements. J Geophys Res Atmos 102:29429-29443. https://doi. org/10.1029/97jd01107

Demarez V, Duthoit S, Baret F, Weiss M, Dedieu G (2008) Estimation of leaf area and clumping indexes of crops with hemispherical photographs. Agric For Meteorol 148:644-655. https://doi. org/10.1016/j.agrformet.2007.11.015

Eko PM, Johansson U, Petersson N, Bergqvist J, Elfving B, Frisk J (2008) Current growth differences of Norway spruce (Picea abies), Scots pine (Pinus sylvestris) and birch (Betula pendula and Betula pubescens) in different regions in Sweden scand. J For Res 23:307-318. https://doi.org/10.1080/02827580802249126

Engelmark O, Hytteborn H (1999) Coniferous forests. In: Swedish Plant Geography. Acta Phytogeographica Suecica, vol 84, pp 55-74

Fassnacht KS, Gower ST, Norman JM, Mcmurtrie RE (1994) A comparison of optical and direct-methods for estimating foliage surface-area index in forests. Agric For Meteorol 71:183-207. https ://doi.org/10.1016/0168-1923(94)90107-4

Garrigues S et al (2008) Validation and intercomparison of global leaf area index products derived from remote sensing data. J Geophys Res Biogeosci 113:1-20. https://doi.org/10.1029/2007jg000635

Gonzalez-Benecke CA, Jokela EJ, Martin TA (2012) Modeling the effects of stand development, site quality, and silviculture on leaf area index, litterfall, and forest floor accumulations in loblolly and slash pine plantations. For Sci 58:457-471. https://doi. org/10.5849/forsci.11-072

Gower ST, Norman JM (1991) Rapid estimation of leaf-area index in conifer and broad-leaf plantations. Ecology 72:1896-1900. https ://doi.org/10.2307/1940988

Gower ST, Kucharik CJ, Norman JM (1999) Direct and indirect estimation of leaf area index, $\mathrm{f}(\mathrm{APAR})$, and net primary production of terrestrial ecosystems. Remote Sens Environ 70:29-51. https ://doi.org/10.1016/s0034-4257(99)00056-5

Hager H, Sterba H (1985) Specific leaf-area and needle weight of Norway spruce (Picea-Abies) in stands of different densities. Can J For Res 15:389-392

Homolova L, Lukes P, Malenovsky Z, Lhotakova Z, Kaplan V, Hanus J (2013) Measurement methods and variability assessment of the Norway spruce total leaf area: implications for remote sensing. Trees Struct Funct 27:111-121. https://doi.org/10.1007/s0046 8-012-0774-8

Johnson JD (1984) A rapid technique for estimating total surface-area of pine needles. For Sci 30:913-921

Jonckheere I, Fleck S, Nackaerts K, Muys B, Coppin P, Weiss M, Baret F (2004) Review of methods for in situ leaf area index determination: part I. Theories, sensors and hemispherical photography. Agric For Meteorol 121:19-35. https://doi.org/10.1016/j.agrfo rmet.2003.08.027

Konopka B, Pajtik J, Marusak R, Bosela M, Lukac M (2016) Specific leaf area and leaf area index in developing stands of Fagus sylvatica L. and Picea abies Karst. For Ecol Manag 364:52-59. https ://doi.org/10.1016/j.foreco.2015.12.005

Kussner R, Mosandl R (2000) Comparison of direct and indirect estimation of leaf area index in mature Norway spruce stands of eastern Germany. Can J For Res 30:440-447. https://doi.org/10.1139/ cjfr-30-3-440

Kuznetsova A, Brockhoff PB, Christensen RHB (2017) lmertest package: tests in linear mixed effects models. J Stat Softw 82:1-26
Landsberg JJ, Gower ST (1997) Applications of physiological ecology to forest management. Academic Press, San Diego

Lang ARG (1991) Application of some of Cauchy's theorems to estimation of surface-areas of leaves, needles and branches of plants, and light transmittance. Agric For Meteorol 55:191-212. https:// doi.org/10.1016/0168-1923(91)90062-U

Lemeur R, Blad BL (1974) Critical review of light models for estimating shortwave radiation regime of plant canopies. Agric Meteorol 14:255-286. https://doi.org/10.1016/0002-1571(74)90024-7

LI-COR (2013) LAI-2200C plant canopy analyser instruction manual. https://licor.app.boxenterprise.net/s/fqjn5mlu8c1a7zir5qel. Accessed 16 June 2017

Marklund LG (1988) Biomass function for pine, spruce and birch in Sweden vol 45. Department of Forest Survey

Marshall JD, Monserud RA (2003) Foliage height influences specific leaf area of three conifer species. Can J For Res 33:164-170. https ://doi.org/10.1139/X02-158

Mason EG, Diepstraten M, Pinjuv GL, Lasserre JP (2012) Comparison of direct and indirect leaf area index measurements of Pinus radiata D. Don. Agric For Meteorol 166:113-119. https://doi. org/10.1016/j.agrformet.2012.06.013

Mccarthy HR, Oren R, Finzi AC, Ellsworth DS, Kim HS, Johnsen KH, Millar B (2007) Temporal dynamics and spatial variability in the enhancement of canopy leaf area under elevated atmospheric $\mathrm{CO}_{2}$. Glob Change Biol 13:2479-2497. https://doi.org/10.111 1/j.1365-2486.2007.01455.x

Monteith JL (1977) Climate and efficiency of crop production in Britain. Philos Trans R Soc B 281:277-294. https://doi.org/10.1098/ rstb.1977.0140

Niinemets U, Kull O (1995) Effects of light availability and tree size on the architecture of assimilative surface in the canopy of PiceaAbies-variation in shoot structure. Tree Physiol 15:791-798. https://doi.org/10.1093/treephys/15.12.791

Nilson T (1999) Inversion of gap frequency data in forest stands. Agric For Meteorol 98(9):437-448. https://doi.org/10.1016/S0168 -1923(99)00114-8

Pensa M, Jalkanen R, Liblik V (2007) Variation in Scots pine needle longevity and nutrient conservation in different habitats and latitudes. Can J For Res 37:1599-1604. https://doi.org/10.1139/ $\mathrm{X} 07-012$

Riederer M, Kurbasik K, Steinbrecher R, Voss A (1988) Surface areas, lengths and volumes of Picea abies (L.) Karst. needles: determination, biological variability and effect of environmental factors. Trees Struct Funct 2:165-172

Ryan MG, Binkley D, Fownes JH (1997) Age-related decline in forest productivity: pattern and process. Adv Ecol Res 27:213-262. https ://doi.org/10.1016/S0065-2504(08)60009-4

Sampson DA, Allen HL (1995) Direct and indirect estimates of leafarea index (LAI) for lodgepole and loblolly-Pine stands. Trees Struct Funct 9:119-122. https://doi.org/10.1007/bf02418200

Schneider CA, Rasband WS, Eliceiri KW (2012) NIH Image to ImageJ: 25 years of image analysis. Nat Methods 9:671-675. https://doi. org/10.1038/nmeth.2089

Skogsstyrelsen (2014) Swedish statistical yearbook of forestry. Swedish Forest Agency. https://www.skogsstyrelsen.se/globalassets/ statistik/historiskstatistik/skogsstatistisk-arsbok-2010-2014/skogs statistisk-arsbok-2014.pdf. Accessed 25 May 2018

Stclair JB (1994) Genetic-variation in tree structure and its relation to size in Douglas-Fir. 1. Biomass partitioning, foliage efficiency, stem form, and wood density. Can J For Res 24:1226-1235. https ://doi.org/10.1139/x94-161

Stenberg P (1996) Correcting LAI-2000 estimates for the clumping of needles in shoots of conifers. Agric For Meteorol 79:1-8. https:// doi.org/10.1016/0168-1923(95)02274-0

Team RC (2016) R: a language and environment for statistical computing. R Foundation for Statistical Computing, Vienna 
Temesgen H, Weiskittel AR (2006) Leaf mass per area relationships across light gradients in hybrid spruce crowns. Trees Struct Funct 20:522-530. https://doi.org/10.1007/s00468-006-0068-0

Waring R, Landsberg J, Linder S (2016) Tamm review: insights gained from light use and leaf growth efficiency indices. For Ecol Manag 379:232-242. https://doi.org/10.1016/j.foreco.2016.08.023

Weiskittel AR, Maguire DA (2007) Response of Douglas-fir leaf area index and litterfall dynamics to Swiss needle cast in north coastal oregon, USA. Ann For Sci 64:121-132. https://doi.org/10.1051/ forest:2006096

Weiskittel AR, Temesgen H, Wilson DS, Maguire DA (2008) Sources of within- and between-stand variability in specific leaf area of three ecologically distinct conifer species. Ann For Sci 65:103. https://doi.org/10.1051/forest:2007075
Xiao CW, Janssens IA, Yuste JC, Ceulemans R (2006) Variation of specific leaf area and upscaling to leaf area index in mature Scots pine. Trees Struct Funct 20:304-310. https://doi.org/10.1007/ s00468-005-0039-x

Zha TS, Wang KY, Ryyppo A, Kellomaki S (2002) Impact of needle age on the response of respiration in Scots pine to long-term elevation of carbon dioxide concentration and temperature. Tree Physiol 22:1241-1248

Publisher's Note Springer Nature remains neutral with regard to jurisdictional claims in published maps and institutional affiliations. 